\title{
Nitrogen Utilization in a Cereal-Legume Rotation Managed with Sustainable Agricultural Practices
}

\author{
Mariangela Diacono ${ }^{1, *(\mathbb{D}}$, Paola Baldivieso-Freitas ${ }^{2,3}$ and Francisco Xavier Sans Serra ${ }^{2,3}$ \\ 1 Consiglio per la Ricerca in Agricoltura e l'Analisi dell'Economia Agraria-Research Centre for Agriculture \\ and Environment; Via Celso Ulpiani 5, 70125 Bari, Italy \\ 2 Departament de Biologia Evolutiva, Ecologia i Ciències Ambientals (BEECA), Facultat de Biologia, \\ Universitat de Barcelona, Av. Diagonal 643, 08028 Barcelona, Spain, pbaldiviesofreitas@gmail.com (P.B.-F.); \\ fsans@ub.edu (F.X.S.S.) \\ 3 Biodiversity Research Institute (IRBio), Universitat de Barcelona, 08028 Barcelona, Spain \\ * Correspondence: mariangela.diacono@crea.gov.it; Tel.: +39-080-5475052
}

Received: 20 January 2019; Accepted: 25 February 2019; Published: 26 February 2019

check for updates

\begin{abstract}
Optimization of the nitrogen $(\mathrm{N})$ inputs and minimization of nutrient losses strongly affect yields in crop rotations. The aim of this research was to evaluate the effect of agricultural practices on yield and $\mathrm{N}$ use in a 4-year cereal-legume rotation in organic farming and to identify the best combination of these practices. The following treatments were compared: conventional plough $(\mathrm{P}) \mathrm{vs}$. reduced chisel (RC) tillage; composted farmyard manure (F) vs. unfertilized control (NF); and green manure (GM) vs. no green manure (NoM). No significant differences were found for $\mathrm{N}$ use efficiency between $\mathrm{P}$ and RC in each crop. The results suggested that legumes in the tested rotation do not need supplemental $\mathrm{N}$ fertilization, particularly if combining GM and F. The use of composted farmyard manure should be considered in a long-term fertilization plan for cereals, to allow a higher efficiency in $\mathrm{N}$ use. The residual effect of fertilization over time, along with the site-specific pedo-climatic conditions, should also be considered. In both tested tillage approaches, soil $\mathrm{N}$ surplus was the highest in plots combining GM and F (i.e., more than $680 \mathrm{~kg} \mathrm{~N} \mathrm{ha}^{-1}$ in combination with RC vs. about $140 \mathrm{~kg} \mathrm{~N} \mathrm{ha}^{-1}$ for RC without fertilization), with a risk of $\mathrm{N}$ losses by leaching. The $\mathrm{N}$ deficit in NoM-NF both combined with $\mathrm{P}$ and RC would indicate that these treatment combinations are not sustainable for the utilized crops in the field experiment. Therefore, the combination of the tested practices should be carefully assessed to sustain soil fertility and crop production.
\end{abstract}

Keywords: organic farming; crop rotation; four-year experiment; organic fertilizer; green manure; $\mathrm{N}$ balance

\section{Introduction}

The debate about sustainable agriculture has fostered interest in crop rotations for their effects on nitrogen $(\mathrm{N})$ utilization efficiency and the promotion of profitability and resource efficient farming. In particular, different authors found that cereal-legume rotations are more productive than continuous cereal cropping [1,2] and can more efficiently use the limited rainfall in a Mediterranean environment [3].

In crop rotations on organic farms, yields depend both on the optimization of the $\mathrm{N}$ inputs and reduction of nutrient losses. According to Davis [4], in properly designed rotational systems, cover crops can sustain cash crop production by reducing soil erosion and $\mathrm{N}$ losses from leaching and by increasing soil organic matter. The increase of organic matter is obtained when cover crops are incorporated into the soil as green manure. In particular, the use of leguminous cover crops (pure or in mixture) may partially replace off-farm inputs by improving soil $\mathrm{N}$ fertility and increasing the yield 
of the subsequent crop due to $\mathrm{N}$ fixation in low $\mathrm{C}: \mathrm{N}$ residues $[5,6]$. However, $\mathrm{N}$ from cover crops is often mineralized before the root system of the cash crop is fully developed, thus determining a lack of $\mathrm{N}$ release/uptake synchrony [7]. To reduce $\mathrm{N}$ deficiency, it may be necessary to keep and enhance soil fertility with organic compliant inputs, such as composted farmyard manure and crop residues. Indeed, the organic amendments can reduce nutrient losses, which occur through runoff and leaching, by improving soil structure. This is crucial in the Mediterranean area, which is often characterized by a low amount of soil organic matter that is rapidly mineralized due to high temperatures, reduced rainfall, and plough-based intensive cropping systems [8].

Melero et al. [9] found a significant interaction between crop rotation and tillage, pointing out the differential effect of the soil management system on the soil $\mathrm{N}$ status. In particular, soil conservation tillage increased the total $\mathrm{N}$ in the surface layer more than conventional tillage practices. In addition, according to van Kessel and Hartley [10], conservation tillage can stimulate $\mathrm{N}_{2}$ fixation. This is because soils under conservation tillage systems offer favorable conditions for symbiosis, such as reduced soil temperature and greater water availability, which result from increased aggregates stability and a high number of macropores [11].

Recent attempts have been made to assess the sustainability and crop performance of cropping systems in which cover crops and organic fertilization strategies were combined [12-14]. However, there is still a substantial lack of knowledge on such combined practices (i.e., cover crops and organic fertilization), particularly regarding the assessment of $\mathrm{N}$ efficiency in organic cropping systems in a Mediterranean environment. Therefore, the objective of this research was to study the effect of the combination of different agro-ecological practices (reduced soil tillage, organic fertilization, and green manure) on crop productions and $\mathrm{N}$ use in a cereal-legume rotation in organic farming, under Mediterranean conditions. The hypothesis was that $\mathrm{N}$ availability and $\mathrm{N}$ use efficiency by green manuring and organic fertilizers could be affected by reduced tillage. Since a growing number of agro-ecologists have argued that the productivity of farmlands should be maximized with the increase of uptake efficiency of $\mathrm{N}$ inputs [15], the aim was also to identify the best combination of the adopted agronomic measures in terms of $\mathrm{N}$ balance and $\mathrm{N}$ efficiency parameters.

\section{Materials and Methods}

\subsection{Site of Study}

In 2011, a mid-term (4-year) field experiment was established in the Rural Area of Gallecs, which is a suburban agricultural land area in Catalonia (Spain), located $15 \mathrm{~km}$ North of Barcelona $\left(41^{\circ} 33^{\prime} 31.9^{\prime \prime} \mathrm{N} 2^{\circ} 11^{\prime} 59.5^{\prime \prime} \mathrm{E}, 90 \mathrm{~m}\right.$ above sea level). The area has a Mediterranean climate, and the mean annual temperature and precipitation are $14.6^{\circ} \mathrm{C}$ and $629.2 \mathrm{~mm}$, respectively.

Over the period from December 2011 to July 2012, the total rainfall was $221 \mathrm{~mm}$, showing an increasing trend up to a peak in April and May ( 85 and $72 \mathrm{~mm}$, respectively), followed by a notable decrease in June ( $5 \mathrm{~mm}$; Figure S1).

The mean monthly temperature showed the highest values in June and July ( 23 and $24{ }^{\circ} \mathrm{C}$, respectively). Similarly, the chickpea (in 2013) cycle had higher rainfall in April ( $84 \mathrm{~mm}$, respectively) and the highest mean temperature in July $\left(25^{\circ} \mathrm{C}\right)$, whereas the total rainfall was $175 \mathrm{~mm}$. The wheat cycle (2013-2014) was characterized by a more variable rainfall pattern, showing peaks in January (39 mm), May (51 mm), and August (52 $\mathrm{mm}$ ) and a total rainfall of $294 \mathrm{~mm}$ over the period. The highest mean monthly temperature values were found in July and August (approximately $23^{\circ} \mathrm{C}$ for both). Finally, during lentil cropping (2015), total rainfall was very low from April to August (146 mm), reaching a peak in August $(56 \mathrm{~mm})$, when the crop was destroyed and incorporated into the soil because of no seed production. From April to June, which is the most important period for lentil growth, the rainfall was $67.5 \%$ lower than the mean of the last 30 years. The temperature was the highest in July $\left(27^{\circ} \mathrm{C}\right)$. 
The soil was loamy-clay, classified as a Haplic Cambisol according to the Soil Taxonomy definition [16].

At the beginning of the field experiment, the main physical-chemical soil characteristics were on average: $43.3 \pm 6.9 \%$ sand, $26.9 \pm 4.7 \%$, loam and $29.7 \pm 3.7 \%$ clay; soil organic matter $1.5 \pm 0.1 \%$ [17], and $\mathrm{pH}\left(\mathrm{H}_{2} \mathrm{O}\right) 8.1 \pm 0.1$. The field had been under organic management for five years before the trial, with typical Mediterranean crop rotations of cereals and legumes for human feed. The levels of $\mathrm{N}^{-\mathrm{NO}_{3}}$ ( $\left.2 \mathrm{mg} \mathrm{kg}^{-1}\right)$, P-Olsen $\left(16.78 \mathrm{mg} \mathrm{kg}^{-1}\right)$, and $\mathrm{K}\left(252.6 \mathrm{mg} \mathrm{kg}^{-1}\right)$ were common values in the area and compatible with agricultural activities.

\subsection{Experimental Setup and Treatments}

The field experiment consisted of an organic cereal-legume crop rotation in a strip-split-block design, with three factors (with two levels each) and four replications. The following treatments were compared: (1) tillage system (i.e., conventional plough (P) vs. reduced chisel (RC)); (2) organic amendment (i.e., composted farmyard manure (F) vs. unfertilized control (NF)); and (3) green manuring (i.e., green manure (GM) vs. no green manure (NoM)). The factors were arranged with tillage treatments laid out in vertical strips, which were split into subplots with different green manure applications. Fertilization was horizontally stripped across the split-plot experiment. The entire experiment was replicated four times.

The P treatment consisted of a mouldboard plough (soil layers inversion at $25 \mathrm{~cm}$ depth; EG 85-240-8, Kverneland, Morrinsville, Waikato, New Zealand) and a rotary harrow (5 cm depth; HR3003D, Kuhn, Saverne, Cedex, France) for seedbed preparation. For the RC tillage system, a chisel plough (no soil layers inversion, approximately $25 \mathrm{~cm}$ depth; KCCC 1187-A00, Kverneland, Morrinsville, Waikato, New Zealand) and a rotary harrow $(5 \mathrm{~cm}$ depth) were used.

The composted farmyard manure $(\mathrm{F})$ consisted of partially composted cattle manure and vegetable residues. It was obtained according to the normal practices used in the area, by gradually accumulating the material that was seasonally available, without managing or controlling the process. The composted farmyard manure was applied every year before sowing the main crop. The $\mathrm{N}$ content of composted manure was analyzed before application to the soil. The total amount of manure applied depended on each crop, ranging as follows: (i) 100-200 kg N/ha/year for cereals and (ii) $<100 \mathrm{~kg} \mathrm{~N} / \mathrm{ha}$ /year for legumes. In more detail, the used amounts per crop were: $134.60 \mathrm{~kg} \mathrm{~N} \mathrm{ha}^{-1}$ for spelt, $138.28 \mathrm{~kg} \mathrm{~N} \mathrm{ha}^{-1}$ for wheat, $40.04 \mathrm{~kg} \mathrm{~N} \mathrm{ha}^{-1}$ for chickpea, and $62.36 \mathrm{~kg} \mathrm{~N} \mathrm{ha}^{-1}$ for lentil. The organic amendment was mixed into the soil by means of a plough or chisel, depending on the tillage treatment.

In September 2012 and 2014 cover crops were sown before each legume cash crop in the GM plots. Amixture of different crop species in different proportions and with appropriate sowing density was used: oat (Avena sativa L., 30.92\%, $45.8 \mathrm{~kg} \mathrm{ha}^{-1}$ ), white mustard (Sinapis alba L., 1.01\%, $1.5 \mathrm{~kg} \mathrm{ha}^{-1}$ ), bitter vetch (Vicia ervilia L. Willd., 41.23\%, $61 \mathrm{~kg} \mathrm{ha}^{-1}$ ), and common vetch (Vicia sativa L., $26.80 \%$, $39.7 \mathrm{~kg} \mathrm{ha}^{-1}$ ). To build up soil organic matter in the long-term, since the rotation was setup in organic farming, we looked for a high biomass-producing cover crop mix, including non-legume and legume crops. We chose this mixture considering its widespread use by the local organic farmers.

At the end of March, green manure was incorporated into the soil by disc harrowing.

The four-year rotation was carried out with the following cash crops: spelt (Triticum spelta L., 2011-2012 season), chickpea (Cicer arietinum L. cv. Menut, 2013), winter wheat (Triticum aestivum L. cv. Montcada, 2013-2014 season), and lentil (Lens culinaris Medik. cv. Pardina, 2015). The crops were cultivated on 32 plots each of $156 \mathrm{~m}^{2}(13 \mathrm{~m} \times 12 \mathrm{~m})$, thus allowing the use of regular-sized farming equipment. The spelt crop was sown on 14 December $2011\left(195 \mathrm{~kg}\right.$ seeds ha $\left.{ }^{-1}\right)$ and it was harvested on 12 July 2012. The chickpea crop was sown on 13 April $2013\left(30 \mathrm{~kg} \mathrm{ha}^{-1}\right)$ and it was harvested on 31 July 2013. The wheat crop was sown on 16 December $2013\left(220 \mathrm{~kg} \mathrm{ha}^{-1}\right)$ and it was harvested on 12 August 2014. Finally, the lentil crop was sown on 31 March 2015, but no yield was obtained from this crop. 
During the first year of the crop rotation, no weeds management was performed due to unfavorable weather conditions. In the second year, weeds were controlled with an inter-row cultivator adapted to pass between the seeding rows of the chickpeas. In wheat cropping season, weeds were mowed with a flex-tines harrow, while during the last year of the rotation, the lentil crop was characterized by heavy competition with weeds, which were controlled manually.

\subsection{Measurements}

\subsubsection{Crop Measurements}

Four permanent frames of $1 \mathrm{~m} \times 1 \mathrm{~m}$ were randomly established in each plot. The total aboveground biomass of the cash crops was collected before harvest in each frame and oven-dried at $60{ }^{\circ} \mathrm{C}$ for $48 \mathrm{~h}$, then biomass dry matter was determined. All samplings were limited to the inner $9 \mathrm{~m} \times$ $8 \mathrm{~m}$ of each plot. The plant $\mathrm{N}$ content (\% N) was evaluated using the Dumas combustion method [18], allowing for the calculation of crop $\mathrm{N}$ uptake $\left(\mathrm{N}\right.$ content $\times$ dry biomass; $\left.\mathrm{kg} \mathrm{ha}^{-1}\right)$. Nitrogen use indices were calculated as follows: $\mathrm{N}$ utilization efficiency index (NUE), as the ratio of yield to $\mathrm{N}$ uptake $\left(\mathrm{kg} \mathrm{kg}^{-1}\right)$, and $\mathrm{N}$ uptake efficiency, as the ratio of total plant $\mathrm{N}$ uptake to total $\mathrm{N}$ supply $\left(\mathrm{kg} \mathrm{kg}^{-1}\right)$, according to Montemurro [19] and Lòpez-Bellido and Lòpez-Bellido [20].

Cereals and chickpeas were harvested by a plot combine (Elite, WINTERSTEIGER, Inc., Ried, im Innkreis, Austria) in the inner $9 \mathrm{~m} \times 8 \mathrm{~m}$ of each plot and grain yields were determined. The straw of the crops was not removed from the field. The spelt straw was chopped by a straw chopper hammer (BB-P-240, Belafer, Fraga, Zaragoza, Spain) before it was incorporated into the soil by disc harrowing. The lentil crop did not produce grain because of extended drought coupled with high temperatures during the last phenological stages, which dramatically affected flowering; therefore, no final product was obtained.

\subsubsection{Soil Sampling and Analysis}

At the beginning (November 2011) and the end (November 2015) of the field trial, 20 soil cores of $2.5 \mathrm{~cm}$ of diameter were systematically extracted at a $0-20 \mathrm{~cm}$ soil depth (i.e., reduced depth, since it is a soil prone to deep compaction) every $2 \mathrm{~m}$ in each plot.

Each set of 20 cores extracted at each plot constituted a soil sample. Soil samples were air dried, ground to pass a 2-mm sieve, and then total soil nitrogen (SN) content was determined through dry combustion [21] with a Truspec CHNS analyzer (LECOC, Saint Joseph, MI, USA). The soil bulk density of each plot was used to determine SN. The overall mean values were 1.43 and $1.36 \mathrm{~g} \mathrm{~cm}^{3}$ in 2011 and 2015, respectively.

An $\mathrm{N}$ surface balance for the whole experiment for each treatment combination, considering different authors [22-24], was calculated as follows:

$$
N \text { surplus } / \text { deficit }=(N \text { supply }+(\text { Final SN }- \text { Initial SN }))-N \text { uptake }
$$

where:

$N$ supply $=N$ from fertilizer $+N$ fixed by green manure $+N$ fixed by legume cash crop $+N$ deposition (estimated as $18 \mathrm{~kg} \mathrm{~N}^{-1}$ according to García-Gómez et al. [25]).

According to the Organisation for Economic Co-operation and Development (OECD) and the statistical office of the European Union (EUROSTAT) [26], N contained in seeds was not included in calculations.

Final SN = SN in November 2015.

Initial SN = SN in November 2011.

Moreover, $\mathrm{N}$ left in the soil after the legume crop was determined as the difference between the $\mathrm{N}$ supply and $\mathrm{N}$ uptake. 
Calculation of $\mathrm{N}$-fixation values (BNF, biologically nitrogen fixation) was made based on the formula proposed by Høgh-Jensen et al. [27], modified by Hansen et al. [28]:

$$
B N F=\text { yield_DM } \times N \text { content } \times N \text { fix } \times 1.55
$$

where:

yield_DM: $\mathrm{t} \mathrm{ha}^{-1}$ of yield dry matter;

Nfix: \% of aboveground nitrogen derived from the atmosphere according to Amossé et al. [29];

1.55: coefficient obtained from $\left(1+\mathrm{N}_{\text {root+stubble }}+\mathrm{N}_{\text {transsoil }}+\mathrm{N}_{\text {immobile }}\right)$, according to Hansen et al. [28].

\subsection{Statistical Analysis}

Data analysis was carried out separately for each year; the tillage system and organic amendment were factors for cereals, while tillage system, organic amendment, and green manuring were factors for legume crops. Differences between experimental treatments were evaluated by applying the Student-Newman-Keuls test (SNK) at $p \leq 0.05$ probability level. The statistical analysis was carried out using PROC GLM by SAS/STAT software, release 9.3, 2012 (SAS Institute Inc., Cary, NC, USA). The PROC BOXPLOT procedure was used to generate box plots for treatment interactions between green manuring and organic amendment on the $\mathrm{N}$ uptake efficiency.

\section{Results}

3.1. Effects of Tillage System, Organic Amendment, and Green Manuring on Crops Biomass, Yield, and N Efficiency Parameters

Significant main effects of organic amendment on spelt and wheat for all parameters (crops biomass, yield, and $\mathrm{N}$ efficiency parameters) were found (Table 1).

The amendment also revealed a significant effect on $\mathrm{N}$ uptake efficiency for both chickpea and lentil crops (Table 2). Moreover, green manuring had a significant effect on the $\mathrm{N}$ uptake efficiency of both legumes and the two-way interaction of amendment $\times$ green manuring had a significant effect as well.

Table 3 reports crops biomass and yield, except yield for the lentil crop (since its production failed). Significant differences were found between amendment treatments in both cereals. In particular, spelt biomass and yield were significantly higher for $\mathrm{F}$ by $21 \%$ and $15 \%$, respectively, compared to that of NF. In the wheat crop, biomass and yield were higher in F by $27 \%$ and $36 \%$, respectively.

Cash crop $\mathrm{N}$ efficiency parameters (NUE and N uptake efficiency) revealed significant differences between fertilization treatments for cereals, the F treatment determining lower values than NF (Table 4).

Table 1. Analysis of variance for the effect of tillage system and organic amendment on biomass (dry matter), yield, and $\mathrm{N}$ efficiency parameters of spelt and wheat crops. $\mathrm{NUE}=\mathrm{N}$ utilization efficiency index.

\begin{tabular}{|c|c|c|c|c|c|c|c|c|c|c|}
\hline \multirow[b]{2}{*}{ Treatments } & Spelt & Wheat & Spelt & Wheat & Spelt & Wheat & Spelt & Wheat & Spelt & Wheat \\
\hline & \multicolumn{2}{|c|}{$\begin{array}{l}\text { Biomass } \\
\left(t \text { ha }^{-1}\right)\end{array}$} & \multicolumn{2}{|c|}{$\begin{array}{l}\text { Yield } \\
\left(t \mathrm{ha}^{-1}\right)\end{array}$} & \multicolumn{2}{|c|}{$\begin{array}{l}\text { N Uptake } \\
\left(\mathrm{kg} \mathrm{ha}^{-1}\right)\end{array}$} & \multicolumn{2}{|c|}{$\begin{array}{c}\mathrm{NUE} \\
\left(\mathrm{kg} \mathrm{kg}^{-1}\right)\end{array}$} & \multicolumn{2}{|c|}{$\begin{array}{c}\text { N Uptake Efficiency } \\
\left(\mathrm{kg} \mathrm{kg}^{-1}\right)\end{array}$} \\
\hline Tillage $(\mathrm{T})$ & ns & ns & ns & ns & ns & ns & $\mathrm{ns}$ & ns & ns & ns \\
\hline Amendment (A) & $* * *$ & $* *$ & $* * *$ & $* *$ & $* * *$ & $* * *$ & $* * *$ & $* *$ & $* * *$ & $* * *$ \\
\hline $\mathrm{T} \times \mathrm{A}$ & ns & ns & ns & ns & ns & ns & ns & ns & ns & ns \\
\hline
\end{tabular}

Notes: ${ }^{* *},{ }^{* * *}=$ Significant at the $p<0.01$ and 0.001 probability levels, respectively. ns $=$ Not significant. 
Table 2. Analysis of variance for the effect of tillage system, organic amendment, and green manuring on biomass (dry matter), yield, and N efficiency parameters of chickpea and lentil crops.

\begin{tabular}{|c|c|c|c|c|c|c|c|c|c|c|}
\hline \multirow{2}{*}{ Treatments } & Chickpea & Lentil & Chickpea & Lentil & Chickpea & Lentil & Chickpea & Lentil & Chickpea & Lentil \\
\hline & \multicolumn{2}{|c|}{$\begin{array}{l}\text { Biomass } \\
\left(\mathrm{t} \mathrm{ha}^{-1}\right)\end{array}$} & \multicolumn{2}{|c|}{$\begin{array}{l}\text { Yield } \\
\left(t \mathrm{ha}^{-1}\right)\end{array}$} & \multicolumn{2}{|c|}{$\begin{array}{l}\text { N Uptake } \\
\left(\text { kg ha }^{-1}\right)\end{array}$} & \multicolumn{2}{|c|}{$\begin{array}{c}\text { NUE } \\
\left(\mathrm{kg} \mathrm{kg}^{-1}\right)\end{array}$} & \multicolumn{2}{|c|}{$\begin{array}{c}\text { N Uptake Efficiency } \\
\left(\mathrm{kg} \mathrm{kg}^{-1}\right)\end{array}$} \\
\hline Tillage $(\mathrm{T})$ & ns & ns & ns & - & ns & ns & ns & - & $\mathrm{ns}$ & ns \\
\hline Amendment (A) & ns & ns & ns & - & ns & ns & ns & - & $* * *$ & $* * *$ \\
\hline Green manuring $(\mathrm{G})$ & ns & ns & ns & - & ns & ns & ns & - & $* * *$ & $* * *$ \\
\hline $\mathrm{T} \times \mathrm{A}$ & ns & ns & ns & - & ns & ns & ns & - & ns & ns \\
\hline $\mathrm{T} \times \mathrm{G}$ & ns & ns & ns & - & ns & ns & ns & - & $\mathrm{ns}$ & ns \\
\hline$A \times G$ & ns & ns & ns & - & ns & ns & ns & - & $* * *$ & $* * *$ \\
\hline $\mathrm{T} \times \mathrm{A} \times \mathrm{G}$ & ns & $\mathrm{ns}$ & ns & - & ns & ns & ns & - & ns & ns \\
\hline
\end{tabular}

Notes: ${ }^{* * *}=$ Significant at the $p<0.001$ probability level; ns = Not significant; the dash indicates: no yield obtained for lentil.

Table 3. Cash crops' biomass and yield (except for the lentil crop). Means ( \pm Std Dev) are presented under different tillage systems, organic amendments, and green manuring strategies (P: conventional plough; RC: reduced chisel; F: composted farmyard manure; NF: unfertilized control; GM: green manure; NoM: no green manure)

\begin{tabular}{|c|c|c|c|c|c|c|c|c|}
\hline \multirow[b]{2}{*}{ Treatments } & \multicolumn{2}{|c|}{ Spelt } & \multicolumn{2}{|c|}{ Chickpea } & \multicolumn{2}{|c|}{ Wheat } & \multicolumn{2}{|c|}{ Lentil } \\
\hline & $\begin{array}{l}\text { Biomass } \\
\left(\mathrm{t} \mathrm{ha} \mathbf{a}^{-1}\right)\end{array}$ & $\begin{array}{l}\text { Yield } \\
\left(t \text { ha }^{-1}\right)\end{array}$ & $\begin{array}{l}\text { Biomass } \\
\left(\mathrm{t} \mathrm{ha} \mathrm{h}^{-1}\right)\end{array}$ & $\begin{array}{l}\text { Yield } \\
\left(\mathrm{t} \mathrm{ha}^{-1}\right)\end{array}$ & $\begin{array}{l}\text { Biomass } \\
\left(\mathrm{t} \mathrm{ha}^{-1}\right)\end{array}$ & $\begin{array}{c}\text { Yield } \\
\left(t h^{-1}\right)\end{array}$ & $\begin{array}{l}\text { Biomass } \\
\left(\mathrm{t} \mathrm{ha} \mathbf{a}^{-1}\right)\end{array}$ & $\begin{array}{c}\text { Yield } \\
\left(t \mathrm{ha}^{-1}\right)\end{array}$ \\
\hline \multicolumn{9}{|l|}{ Tillage } \\
\hline $\mathrm{P}$ & $6.80 \mathrm{a} \pm 1.02$ & $2.33 a \pm 0.19$ & $0.87 a \pm 0.31$ & $0.38 a \pm 0.13$ & $8.00 \mathrm{a} \pm 1.51$ & $3.23 a \pm 0.71$ & $0.91 \mathrm{a} \pm 0.27$ & - \\
\hline $\mathrm{RC}$ & $6.21 \mathrm{a} \pm 0.87$ & $2.32 \mathrm{a} \pm 0.32$ & $0.84 a \pm 0.29$ & $0.38 \mathrm{a} \pm 0.16$ & $7.75 a \pm 1.44$ & $3.16 \mathrm{a} \pm 0.71$ & $0.67 a \pm 0.67$ & - \\
\hline \multicolumn{9}{|l|}{ Amendment } \\
\hline $\mathrm{F}$ & $7.11 \mathrm{a} \pm 0.69$ & $2.49 a \pm 0.18$ & $0.76 a \pm 0.28$ & $0.32 a \pm 0.15$ & $8.81 \mathrm{a} \pm 1.14$ & $3.68 a \pm 0.53$ & $0.72 a \pm 0.24$ & - \\
\hline NF & $5.89 b \pm 0.84$ & $2.16 b \pm 0.21$ & $0.95 a \pm 0.27$ & $0.44 a \pm 0.09$ & $6.94 b \pm 1.11$ & $2.71 b \pm 0.48$ & $0.86 a \pm 0.30$ & - \\
\hline \multicolumn{9}{|l|}{ Green manuring } \\
\hline GM & - & - & $0.86 a \pm 0.29$ & $0.39 a \pm 0.15$ & - & - & $0.81 a \pm 0.28$ & - \\
\hline NoM & - & - & $0.85 a \pm 0.30$ & $0.38 a \pm 0.13$ & - & - & $0.76 a \pm 0.28$ & - \\
\hline Means & 6.50 & 2.33 & 0.86 & 0.38 & 7.88 & 3.20 & 0.79 & - \\
\hline
\end{tabular}

Notes: For each factor, the mean values in each column followed by a different letter are significantly different between treatments according to the Student-Newman-Keuls test (SNK); the dash indicates: no yield obtained for lentil. 
Table 4. Cash crops' N efficiency parameters. Means ( \pm Std Dev) are presented under different tillage systems, green manuring, and organic amendment strategies (P: conventional plough; RC: reduced chisel; F: composted farmyard manure; NF: unfertilized control; GM: green manure; NoM: no green manure).

\begin{tabular}{|c|c|c|c|c|c|c|c|}
\hline \multirow[b]{2}{*}{ Treatment } & \multicolumn{2}{|r|}{ Spelt } & \multicolumn{2}{|c|}{ Chickpea } & \multicolumn{2}{|c|}{ Wheat } & \multirow{2}{*}{$\begin{array}{c}\text { Lentil } \\
\begin{array}{c}\text { N Uptake Efficiency } \\
\left(\mathrm{kg} \mathrm{kg}^{-1}\right)\end{array}\end{array}$} \\
\hline & $\begin{array}{c}\text { NUE } \\
\left(\mathrm{kg} \mathrm{kg}^{-1}\right)\end{array}$ & $\begin{array}{l}\text { N Uptake Efficiency } \\
\left(\mathrm{kg} \mathrm{kg}^{-1}\right)\end{array}$ & $\begin{array}{c}\text { NUE } \\
\left(\mathrm{kg} \mathrm{kg}^{-1}\right)\end{array}$ & $\begin{array}{l}\text { N Uptake Efficiency } \\
\left(\mathrm{kg} \mathrm{kg}^{-1}\right)\end{array}$ & $\begin{array}{c}\text { NUE } \\
\left(\mathrm{kg} \mathrm{kg}^{-1}\right)\end{array}$ & $\begin{array}{l}\text { N Uptake Efficiency } \\
\left(\mathrm{kg} \mathrm{kg}^{-1}\right)\end{array}$ & \\
\hline \multicolumn{8}{|l|}{ Tillage } \\
\hline $\mathrm{RC}$ & $20.47 a \pm 3.37$ & $0.55 a \pm 0.43$ & $8.91 \mathrm{a} \pm 2.80$ & $0.72 a \pm 0.48$ & $17.75 a \pm 3.02$ & $0.63 a \pm 0.47$ & $0.54 a \pm 0.48$ \\
\hline \multicolumn{8}{|l|}{ Amendment } \\
\hline F & $17.52 b \pm 3.34$ & $0.13 b \pm 0.02$ & $7.43 a \pm 1.80$ & $0.54 b \pm 0.22$ & $15.37 \mathrm{~b} \pm 2.27$ & $0.17 \mathrm{~b} \pm 0.01$ & $0.27 \mathrm{~b} \pm 0.08$ \\
\hline NF & $21.67 \mathrm{a} \pm 2.50$ & $0.95 a \pm 0.07$ & $9.72 a \pm 2.65$ & $0.91 \mathrm{a} \pm 0.56$ & $20.22 a \pm 2.20$ & $1.08 a \pm 0.08$ & $0.88 a \pm 0.55$ \\
\hline \multicolumn{8}{|l|}{ Green manuring } \\
\hline GM & - & - & $8.36 a \pm 2.27$ & $0.37 \mathrm{~b} \pm 0.06$ & - & - & $0.28 b \pm 0.10$ \\
\hline NoM & - & - & $8.78 a \pm 2.80$ & $1.08 a \pm 0.40$ & - & - & $0.86 a \pm 0.56$ \\
\hline Means & 19.60 & 0.54 & 8.57 & 0.73 & 17.80 & 0.63 & 0.57 \\
\hline
\end{tabular}

Notes: For each factor, the mean values in each column followed by a different letter are significantly different between treatments according to SNK 
For the spelt crop, the NUE and N uptake efficiency were significantly lower in F than those in NF by about $19 \%$ and $86 \%$, respectively, whereas for wheat, they were lower by about $24 \%$ and $84 \%$ in $\mathrm{F}$ than in NF, respectively. As for the two leguminous crops, $\mathrm{N}$ uptake efficiency showed better results without green manure and organic amendment (NoM and NF), in comparison with GM and F plots. However, in this case, the two-way interaction between green manuring and organic amendment treatments, which had a significant effect, should be analyzed (Figure 1). The interaction allows for the determination of whether a particular combination of treatments leads to results that would not be anticipated on the basis of the main effects.

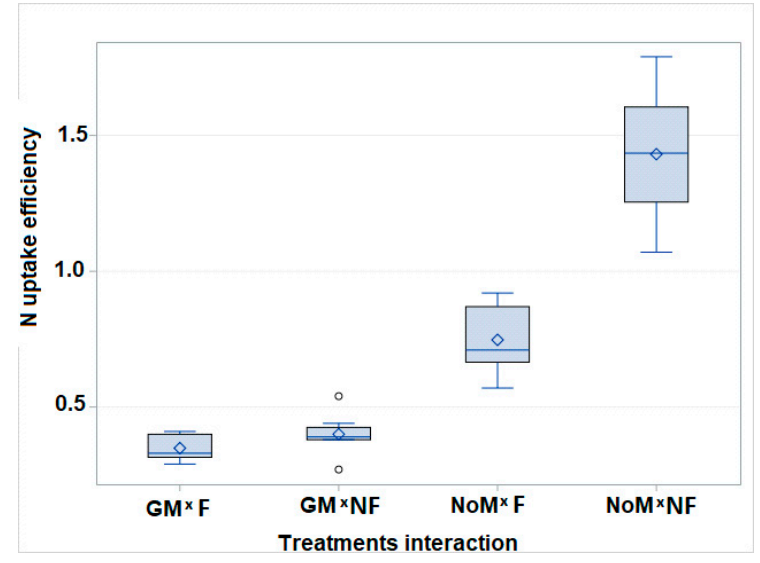

(a)

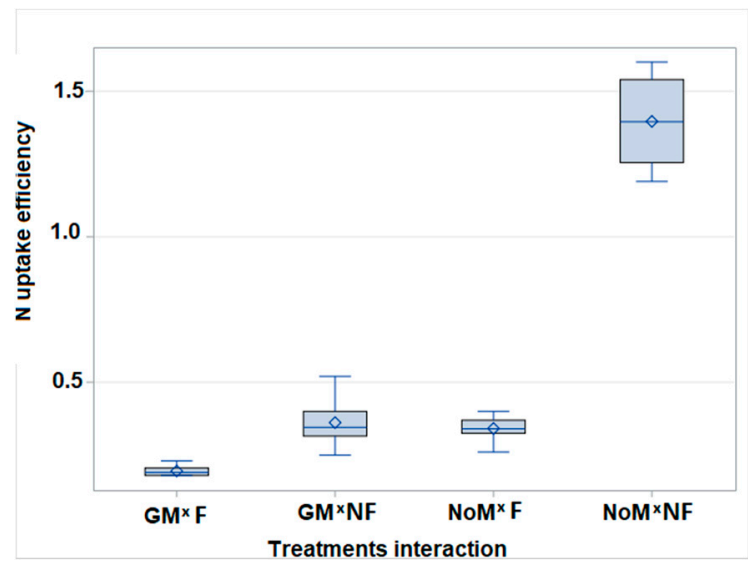

(b)

Figure 1. Box plots for the effect of the interaction between green manure and fertilization on the $\mathrm{N}$ uptake efficiency (total plant $\mathrm{N}$ to total $\mathrm{N}$ supply ratio; $\mathrm{kg} \mathrm{kg}^{-1}$ ) of the legume crops: (a) chickpea and (b) lentil (GM: green manure; NoM: no green manure; F: composted farmyard manure; NF: unfertilized control).

The best $\mathrm{N}$ uptake efficiency results were obtained for the double negative control $(\mathrm{NoM} \times \mathrm{NF})$ in both crops (1.43 and $1.39 \mathrm{~kg} \mathrm{~kg}^{-1}$ in chickpea and lentil, respectively). The chickpea crop showed on average higher $\mathrm{N}$ uptake efficiency than the lentil crop. The lowest values were found in GM both in the interaction with $\mathrm{F}$ and NF (being lower, on average, by $74 \%$ than $\mathrm{NoM} \times \mathrm{NF}$ ), whereas NoM $\times$ F showed intermediate values. In the lentil crop, no substantial differences were found among the other interactions, which showed significantly lower values (particularly for GM $\times \mathrm{F}$ treatments combination) compared to $\mathrm{NoM} \times \mathrm{NF}$.

\section{2. $N$ Balance}

Table 5 shows the soil $\mathrm{N}$ surplus/deficit by each treatment combination over the 4 -year experiment.

The chickpea and lentil crops had different performance. In particular, the chickpea crop absorbed 38-53 kg N ha ${ }^{-1}$ and the lentil crop absorbed 16-34 $\mathrm{kg} \mathrm{N} \mathrm{ha}^{-1}$. Despite the observed difference, the P-GM-NF treatment combination showed the highest absolute value for $\mathrm{N}$ uptake in both crops. The chickpea crop took up $\mathrm{N}$ at a rate slightly higher than the $\mathrm{N}$ supply in $\mathrm{P}-\mathrm{NoM}-\mathrm{NF}$ and RC-NoM-NF treatment combinations. In contrast, the lentil crop always took up less $\mathrm{N}$ than the supplied rate, particularly for P-GM-F and RC-GM-F.

The $\mathrm{N}$ balance results showed that the $\mathrm{N}$ surplus/deficit was the highest in the combinations of GM-F both with P and RC tillage, as well as in RC-NoM-F. An intermediate surplus value was obtained by P-NoM-F. Conversely, the P-NoM-NF and RC-NoM-NF showed the lowest values (deficit of 117 and $94 \mathrm{~kg} \mathrm{~N} \mathrm{ha}^{-1}$, respectively). The other treatment combinations had intermediate results. 
Table 5. Soil $\mathrm{N}$ surplus/deficit $\left(\mathrm{kg} \mathrm{N} \mathrm{ha}^{-1}\right)$ for the whole field experiment divided by treatment combinations (in columns): tillage system, organic amendment, and green manuring (P: conventional plough; RC: reduced chisel; F: composted farmyard manure; NF: unfertilized control; GM: green manure; NoM: no green manure). SN = soil nitrogen at to (2011) and tf (2015); N uptake ( $\mathrm{N}$ content $\times$ dry biomass); $\mathrm{N}$ supply ( $\mathrm{N}$ fertilizer $+\mathrm{N}$ fixed green manure $+\mathrm{N}$ fixed cash crop $+\mathrm{N}$ deposition). The parameters (SN, N uptake, and N supply) in each cropping season (2012 spelt, 2013 chickpea, 2014 wheat, and 2015 lentil) are expressed as $\mathrm{kg} \mathrm{N} \mathrm{ha}^{-1}$.

\begin{tabular}{|c|c|c|c|c|c|c|c|c|}
\hline N Balance & $\begin{array}{c}\text { P } \\
\text { NF } \\
\text { NoM }\end{array}$ & $\begin{array}{c}\text { P } \\
F \\
\text { NoM }\end{array}$ & $\begin{array}{c}\text { RC } \\
\text { NF } \\
\text { NoM }\end{array}$ & $\begin{array}{c}\text { RC } \\
\text { F } \\
\text { NoM }\end{array}$ & $\begin{array}{l}\mathrm{P} \\
\mathrm{NF} \\
\mathrm{GM}\end{array}$ & $\begin{array}{c}\mathbf{P} \\
\mathbf{F} \\
\mathbf{G M}\end{array}$ & $\begin{array}{l}\text { RC } \\
\text { NF } \\
\text { GM }\end{array}$ & $\begin{array}{c}\text { RC } \\
\text { F } \\
\text { GM }\end{array}$ \\
\hline $\begin{array}{l}\mathbf{2 0 1 2} \\
\text { SN t0 } \\
\text { N uptake } \\
\text { N supply }\end{array}$ & $\begin{array}{l}1643 \\
107.3 \\
18.00\end{array}$ & $\begin{array}{l}1643 \\
155.2 \\
152.6\end{array}$ & $\begin{array}{l}1670 \\
95.86 \\
18.00\end{array}$ & $\begin{array}{l}1689 \\
139.3 \\
152.6\end{array}$ & 1640 & 1735 & 1658 & 1703 \\
\hline $\begin{array}{l}2013 \\
\mathrm{~N} \text { uptake } \\
\mathrm{N} \text { supply }\end{array}$ & $\begin{array}{l}46.60 \\
36.76\end{array}$ & $\begin{array}{l}47.90 \\
74.56\end{array}$ & $\begin{array}{l}42.98 \\
36.37\end{array}$ & $\begin{array}{l}40.66 \\
73.17\end{array}$ & $\begin{array}{c}53.17 \\
132.94\end{array}$ & $\begin{array}{c}44.83 \\
161.43\end{array}$ & $\begin{array}{l}51.02 \\
127.1\end{array}$ & $\begin{array}{c}38.14 \\
178.51\end{array}$ \\
\hline $\begin{array}{l}2014 \\
\text { N uptake } \\
\text { N supply }\end{array}$ & $\begin{array}{l}137.9 \\
18.00\end{array}$ & $\begin{array}{l}245.2 \\
152.6\end{array}$ & $\begin{array}{l}131.6 \\
18.00\end{array}$ & $\begin{array}{l}241.9 \\
152.6\end{array}$ & & & & \\
\hline $\begin{array}{l}2015 \\
\text { SN tf } \\
\text { N uptake } \\
\text { N supply }\end{array}$ & $\begin{array}{l}1733 \\
21.60 \\
33.59\end{array}$ & $\begin{array}{l}1987 \\
25.03 \\
80.36\end{array}$ & $\begin{array}{r}1759 \\
18.65 \\
33.59\end{array}$ & $\begin{array}{l}2189 \\
16.11 \\
80.36\end{array}$ & $\begin{array}{l}1727 \\
34.00 \\
74.17\end{array}$ & $\begin{array}{c}2083 \\
23.53 \\
146.26\end{array}$ & $\begin{array}{r}1653 \\
18.45 \\
86.30\end{array}$ & $\begin{array}{c}2118.09 \\
16.03 \\
143.8\end{array}$ \\
\hline $\begin{array}{l}\mathbf{N} \\
\text { surplus/deficit }\end{array}$ & -117 & 331 & -94 & 520 & 206 & 587 & 139 & 683 \\
\hline
\end{tabular}

\section{Discussion}

\subsection{Effect of Treatments on Cash Crops' Agronomic Performance and Nitrogen Utilization}

A higher yield in amended plots than in plots without compost was found, but a low efficiency in $\mathrm{N}$ use in the short-term was also detected. The low $\mathrm{N}$ efficiency could be explained considering that the $\mathrm{N}$ uptake was also dependent on the slow-release of $\mathrm{N}$ by compost mineralization. The obtained results are in agreement with those of Montemurro [30], who found that $\mathrm{N}$ utilization efficiency was not correlated with wheat grain yield. In fact, the more stabilized fraction of the compost could improve soil fertility and influence $\mathrm{N}$ efficiency only in the long run [31].

The type of tillage did not affect $\mathrm{N}$ uptake when associated with various sources of N (Tables 3 and 4), unlike the results of Ishaq et al. [32] who found that tillage (conventional and deep till) and fertilizer treatment had a positive effect on nutrient uptake by a wheat crop. In particular, in our research, NUE values did not show any difference between $\mathrm{P}$ and $\mathrm{RC}$ in all cash crops. This result is in accordance with the results of Montemurro [30] and in contrast to those of Lòpez-Bellido and Lòpez-Bellido [20], who found greater NUE values in the conventional system than in the no-tillage system.

Moreover, the mean values of NUE recorded for cereals were very low, indicating that these crops require a higher $\mathrm{N}$ fertilization rate for optimizing yields. In addition, the variable rainfall distribution during the cycle might have influenced crop $\mathrm{N}$ uptake [33]. The lower values of the $\mathrm{N}$ efficiency parameters in fertilized plots for the two cereal crops, compared to those in the unfertilized plots, were probably related to the specific characteristics of the organic fertilizer used, which was a partially decomposed compost.

As expected, in 2012 and 2014 (corresponding to cereal crops cultivation) the $\mathrm{N}$ uptake was higher than in 2013 and 2015 (i.e., during legumes cropping seasons; Table 5). In general, legumes do not need supplemental $\mathrm{N}$ fertilization, since fertilizer rates exceeding those exerting a "starter $\mathrm{N}$ " effect can reduce nodulation and $\mathrm{N}_{2}$ fixation [34]. In particular, a chickpea crop can obtain at least some $\mathrm{N}$ by $\mathrm{N}_{2}$ fixation, but the proportion of $\mathrm{N}$ fixed is negatively correlated with availability of inorganic $\mathrm{N}$ in the soil [35], considering that the rate of $\mathrm{N}_{2}$ fixation could be suppressed by nitrates. However, in our crop rotation, the chickpea crop showed an $\mathrm{N}$ uptake rate slightly higher than the $\mathrm{N}$ supply for almost all 
treatment combinations (except for RC-NoM-F and RC-GM-F; Table 5). This last result would suggest that unfavorable conditions (e.g., reduced soil water availability, high soil mineralization rate, etc.) for the symbiotic association likely occurred.

In the chickpea crop, the lowest $\mathrm{N}$ uptake efficiency values were found in plots with green manure, irrespective of amendment with compost, thus suggesting that a green manure application preceding this legume crop would not be a suitable solution, since it provides $\mathrm{N}$ that is quickly available by mineralization (negatively influencing $\mathrm{N}_{2}$ fixation as previously explained).

Conversely, the amendment treatment alone could be used, considering that the partially composted farmyard manure can release the $\mathrm{N}$ more slowly during the rotation seasons, although the NUE value probably did not derive only from an effect by composted farmyard manure. The value could also be due to other biotic and abiotic factors, such as pathogens, suboptimal conditions in water status, temperature, and $\mathrm{pH}$, which can influence the success of the legume-Rhizobium association. The obtained results on yield and $\mathrm{N}$ efficiency parameters for the chickpea crop are in accordance with those of Bonfil and Pinthus [36]. The authors reported that the application of $100 \mathrm{~kg} \mathrm{~N} \mathrm{ha}^{-1}$ promoted $\mathrm{N}$ uptake by chickpea without enhancing the final seed yield, possibly because in this case additional $\mathrm{N}$ fertilizer encouraged vegetative growth instead of allocating resources to seed growth.

The lentil crop did not produce seeds, possibly because drought conditions occurred throughout the reproductive period when temperatures were increasing, whereas the mid-vegetative stage was likely less influenced. This would confirm different authors reporting that lentil is most sensitive to drought stress at flowering and pod formation stages [37-39]. Also in the lentil crop, all the green manure $\times$ amendment interactions other than $\mathrm{NoM} \times \mathrm{NF}$ had low $\mathrm{N}$ uptake efficiency values, confirming that additional fertilization for legumes should be avoided, irrespective of the $\mathrm{N}$ source (Figure 1). In particular, the lentil crop took up less $\mathrm{N}$ than the rate supplied, except in plots managed with mouldboard ploughing and fertilized with green manure (Table 5). This result might be explained by a better incorporation of the cover crop residues in the soil by tillage (and subsequent mineralization), since lentil is not able to acquire much Nmin-N from soil layers deeper than $0.6 \mathrm{~m}$, due to its shallow root system [40]. However, it could also have been due to other biotic and abiotic factors, e.g., drought, susceptibility to pests, and diseases.

\subsection{The N Surplus/Deficit}

The $\mathrm{N}$ balance over the whole crop rotation (Table 5), as was expected, shows that the $\mathrm{N}$ surplus was the highest in the GM combinations with F (both P and RC). This would suggest that a share of the $\mathrm{N}$ by green manure and organic amendment remained in the soil, with the risk of $\mathrm{N}$ losses by leaching (with subsequent groundwater contamination) and volatilization. A possible solution could be to avoid GM combined with F in similar cereal-legume rotations, whereas a proper choice and management of cover crop species could allow for the GM treatment alone. Additionally, the detected surplus should be considered in a long-term rotation, including a crop able to uptake this mineralized $\mathrm{N}$, thus avoiding environmental risks like $\mathrm{N}$ leaching, which may contribute to a negative $\mathrm{N}$ balance of agricultural systems [23]. The last speculation is further supported by the surplus found in the $\mathrm{P}-\mathrm{NoM}$ and RC-NoM combinations with $\mathrm{F}$, which would indicate a possibility of maintaining soil fertility with a single $\mathrm{N}$ source (i.e., by $\mathrm{F}$ only), in particular by combining it with $\mathrm{P}$ instead of RC. However, according to Watson et al. [22], the budgets include uncontrollable inputs but do not usually provide information on the fate or origin of any budget surplus, i.e., whether it is lost from the system or 'stored' in the soil. On the other hand, the NoM-NF both combined with P and RC seemed to be unsustainable since they resulted in high $\mathrm{N}$ deficita, whereas the slight surplus obtained by GM-NF both with $\mathrm{P}$ and RC further suggests the need to better manage the cereal-legume rotation to avoid $\mathrm{N}$ loss. This $\mathrm{N}$ surplus might also be considered as an $\mathrm{N}$ reserve for the subsequent crop, on the basis of the $\mathrm{N}$ surplus/deficit approach used, which helped to point out the difference among combinations, including treatments that mainly influenced the levels of $\mathrm{N}$ in the soil. 


\section{Conclusions}

The present study evaluated the effect of different sustainable agronomic practices (i.e., reduced soil tillage, organic amendment, and green manuring) both on crop production and $\mathrm{N}$ use in a cereal-legume rotation in organic farming. Unlike the initial hypothesis, reduced tillage combined with different $\mathrm{N}$ sources did not determine significant differences on yield and $\mathrm{N}$ efficiency parameters. Conversely, both organic amendment and green manuring had significant effects, depending on the crop species, in each cropping cycle.

The results confirmed that legumes do not need supplemental $\mathrm{N}$ fertilization, particularly if combining GM and F. Therefore, these combined practices should be avoided in cereal-legume rotations to prevent $\mathrm{N}$ losses by leaching and volatilization. Moreover, proper choice, depending on the climatic and soil conditions, and management of cover crop species are crucial to maximizing the benefits and providing ecosystem services to crop rotation.

Our results would suggest that the use of compost should be planned in the long term for cereals, to allow a higher efficiency in $\mathrm{N}$ use. Moreover, the residual effect over time and the site-specific pedo-climatic conditions should be considered when formulating fertilizer requirements in such crop rotation.

Further research should focus on the long-term effects of different combinations of various sustainable agricultural practices (e.g., "well stabilized" compost, living mulches, etc.) on several cereal and legume crops in rotation, to be fine-tuned to each pedo-climatic area.

Supplementary Materials: The following are available online at http:/ / www.mdpi.com/2073-4395/9/3/113/s1, Figure S1: Mean monthly temperature (dotted line) and total rainfall (bars) of the area in the last 20 years (top) and during each cash crop growing season of the four-year rotation.

Author Contributions: M.D. contributed to the conceptualization of the paper and data analysis based on the data obtained by the Agroecology Research Group from the University of Barcelona and to the writing of the original draft preparation. P.B.-F. contributed to the collection and analysis of the data. F.X.S.S. contributed to the funding acquisition, conceptualization of the paper, and the data analysis and writing.

Funding: This research was funded by the Ministry of Economy and Competitiveness through the National Institute of Agrarian and Food Research and Technology (INIA), which is part of CORE Organic Plus funding bodies (Coordination of European Transnational Research on Food and Agricultural Ecological Systems), which in turn are partners of FP7 ERA-Net and financed by the European Commission through the TILMAN-ORG and FERTILCROP projects, which allowed the work to be carried out. The research has also been partially funded by the Department of Agriculture, Livestock, Fisheries and Food of Catalonia (projects 2011 AGEC 001, 2012 AGEC 00027, 5305007 2015) and by a pre-doctoral grant from the Spanish Ministry of Education, Culture and Sports to the second author. The grants from the Retibio project (funded by the Organic Farming Office of the Italian Ministry of Agriculture) by the Consiglio per la ricerca in agricoltura e l'analisi dell'economia agraria awarded to M.D. and F.X.S.S. for their internships are gratefully acknowledged.

Acknowledgments: The authors wish to acknowledge the work of all researchers who participated in this experiment. We sincerely thank the people involved in field activities, particularly Alejandro Pérez-Ferrer for technical assistance and Salvi Safont for his experience in managing the machinery needed to perform the field management.

Conflicts of Interest: The authors declare no conflict of interest.

\section{References}

1. López-Bellido, L.; López-Bellido, R.J.; Castillo, J.E.; López-Bellido, F.J. Effect of tillage, crop rotation and nitrogen fertilization on wheat under rainfed Mediterranean conditions. Agron. J. 2000, 92, 1054-1063. [CrossRef]

2. Franke, A.C.; van den Brand, G.J.; Vanlauwe, B.; Giller, K.E. Sustainable intensification through rotations with grain legumes in Sub-Saharan Africa: A review. Agric. Ecosyst. Environ. 2018, 261, 172-185. [CrossRef] [PubMed]

3. Pala, M.; Ryan, J.; Zhang, H.; Singh, M.; Harris, H.C. Water-use efficiency of wheat-based rotation systems in a Mediterranean environment. Agric. Water Manag. 2007, 93, 136-144. [CrossRef]

4. Davis, S.A. Cover-crop roller-crimper contributes to weed management in no-till soybean. Weed Sci. 2010, 58, 300-309. [CrossRef] 
5. Gilmour, J.T.; Mauromostaukos, A.; Gale, P.M.; Norman, R.J. Kinetics of crop residue decomposition: Variability among crops and years. Soil Sci. Soc. Am. J. 1998, 62, 750-755. [CrossRef]

6. Smukler, S.M.; O'Geen, A.T.; Jackson, L.E. Assessment of best management practices for nutrient cycling: A case study on an organic farm in a Mediterranean-type climate. J. Soil Water Conserv. 2012, 67, 16-31. [CrossRef]

7. Pang, X.P.; Letey, J. Organic farming: Challenge of timing nitrogen availability to crop nitrogen requirements. Soil Sci. Soc. Am. J. 2000, 64, 247-253. [CrossRef]

8. Diacono, M.; Persiani, A.; Canali, S.; Montemurro, F. Agronomic performance and sustainability indicators in organic tomato combining different agro-ecological practices. Nutr. Cycl. Agroecosyst. 2018, 112, 101-117. [CrossRef]

9. Melero, S.; López-Bellido, R.J.; López-Bellido, L.; Muñoz-Romero, V.; Moreno, F.; Murillo, J.M. Long-term effect of tillage, rotation and nitrogen fertiliser on soil quality in a Mediterranean Vertisol. Soil Tillage Res. 2011, 114, 97-107. [CrossRef]

10. Van Kessel, C.; Hartley, C. Agricultural management of grain legumes: Has it led to an increase in nitrogen fixation? Field Crop Res. 2000, 65, 165-181. [CrossRef]

11. Souza, A.; Colozzi-Filho, A.; Giller, K.E. The soil microbial community and soil tillage. In Soil Tillage in Agroecosystems; El Titi, A., Ed.; CRC Press: Boca Raton, FL, USA, 2003; pp. 51-81.

12. Mazzoncini, M.; Sapkota, T.B.; Bàrberi, P.; Antichi, D.; Risaliti, R. Long-term effect of tillage, nitrogen fertilization and cover crops on soil organic carbon and total nitrogen content. Soil Tillage Res. 2011, 114, 165-174. [CrossRef]

13. Rizk, M.H. Effect of some legume cover crops and organic fertilizer on petiole nutrient content, productivity and fruit composition of Thompson seedless' grapevines. Acta Hort. 2012, 933, 381-387. [CrossRef]

14. Montemurro, F.; Fiore, A.; Campanelli, G.; Tittarelli, F.; Ledda, L.; Canali, S. Organic fertilization, green manure, and vetch mulch to improve organic zucchini yield and quality. HortScience 2013, 48, 1027-1033. [CrossRef]

15. Crews, T.E.; Peoples, M.B. Legume versus fertilizer sources of nitrogen: Ecological tradeoffs and human needs. Agric. Ecosyst. Environ. 2004, 102, 279-297. [CrossRef]

16. Soil Survey Staff. Soil Taxonomy: A Basic System of Soil Classification for Making and Interpreting Soil Surveys; USDA-NRCS: Washington, DC, USA, 1999.

17. Walkley, A.; Black, I.A. An examination of the Degtjareff method for determining organic carbon in soils: Effect of variations in digestion conditions and of inorganic soil constituents. Soil Sci. 1934, 63, 251-263. [CrossRef]

18. Kalra, Y.P. Hand Book of Reference Methods for Plant Analysis; CRC Press: Boca Raton, FL, USA, 1998; pp. 75-92.

19. Montemurro, F. Are the organic $\mathrm{N}$ fertilizing strategies able to improve lettuce yield, use of nitrogen and $\mathrm{N}$ status? J. Plant Nutr. 2010, 33, 1980-1997. [CrossRef]

20. López-Bellido, R.J.; López-Bellido, L. Efficiency of nitrogen in wheat under Mediterranean conditions: Effect of tillage, crop rotation and N fertilization. Field Crop Res. 2001, 71, 31-46. [CrossRef]

21. Bremner, J.M. Nitrogen total. In Methods of Soil Analysis Part 3: Chemical Methods; Sparks, D.L., Ed.; Soil Science Society of America: Madison, WI, USA, 1996; pp. 1085-1121.

22. Watson, C.A.; Bengtsson, H.; Ebbesvik, M.; Løes, A.K.; Myrbeck, A.; Salomon, E.; Schroder, J.; Stockdale, E.A. A review of farm-scale nutrient budgets for organic farms as a tool for management of soil fertility. Soil Use Manag. 2002, 18, 264-273. [CrossRef]

23. Montemurro, F.; Ferri, D.; Tittarelli, F.; Canali, S.; Vitti, C. Anaerobic digestate and on-farm compost application: effects on lettuce (Lactuca sativa L.) crop production and soil properties. Compost Sci. Util. 2010, 18, 184-193. [CrossRef]

24. Sainju, U.M. Determination of nitrogen balance in agroecosystems. MethodsX 2017, 4, 199-208. [CrossRef] [PubMed]

25. García-Gómez, H.; Garrido, J.L.; Vivanco, M.G.; Lassaletta, L.; Rabago, I.; Àvila, A.; Benedictow, A.; Sánchez, G.; González, A.; González-Fernández, I.; et al. Nitrogen deposition in Spain: Modeled patterns and threatened habitats within the Natura 2000 network. Sci. Total Environ. 2014, 485-486, 450-460.

26. OECD. EUROSTAT Gross Nitrogen Balances Handbook. 2007. Available online: http://www.oecd.org/ greengrowth/sustainable-agriculture/40820234.pdf (accessed on 3 January 2019). 
27. Høgh-Jensen, H.; Loges, R.; Jørgensen, F.V.; Vinther, F.P.; Jensen, E.S. An empirical model for quantification of symbiotic nitrogen fixation in grass-clover mixtures. Agric. Syst. 2004, 82, 181-194. [CrossRef]

28. Hansen, S.; Bernard, M.E.; Richette, P.; Whalen, J.K.; Dörsch, P. Nitrous oxide emissions from a fertile grassland in Western Norway following the application of inorganic and organic fertilizers. Nutr. Cycl. Agroecosyst. 2014, 98, 71-85. [CrossRef]

29. Amossé, C.; Jeuffroy, M.-H.; Mary, B.; David, C. Contribution of relay intercropping with legume cover crops on nitrogen dynamics in organic grain systems. Nutr. Cycl. Agroecosyst. 2013, 97, 1-3.

30. Montemurro, F. Different nitrogen fertilization sources, soil tillage, and crop rotations in winter wheat: Effect on yield, quality, and nitrogen utilization. J. Plant Nutr. 2009, 32, 1-18. [CrossRef]

31. Diacono, M.; Montemurro, F. Long-term effects of organic amendments on soil fertility. A review. Agron. Sustain. Dev. 2010, 30, 401-422. [CrossRef]

32. Ishaq, M.; Ibrahim, M.; Lal, R. Tillage effect on nutrient uptake by wheat and cotton as influenced by fertilizer rate. Soil Tillage Res. 2001, 62, 41-53. [CrossRef]

33. Hasegawa, H.; Denison, R.F. Model predictions of winter rainfall effects on $\mathrm{N}$ dynamics of winter wheat rotation following legume cover crop or fallow. Field Crop Res. 2005, 91, 251-261. [CrossRef]

34. Clayton, G.W.; Rice, W.A.; Lupwayi, N.Z.; Johnston, A.M.; Lafond, G.P.; Grant, C.A.; Walley, F. Inoculant formulation and fertilizer nitrogen effects on field pea: Nodulation, N2 fixation and nitrogen partitioning. Can. J. Plan Sci. 2004, 84, 79-88. [CrossRef]

35. Walley, F.L.; Kyei-Boahen, S.; Hnatowich, G.; Stevenson, C. Nitrogen and phosphorus fertility management for desi and kabuli chickpea. Can. J. Plan Sci. 2005, 85, 73-79. [CrossRef]

36. Bonfil, D.J.; Pinthus, M.J. Response of chickpea to nitrogen and a comparison of the factors affecting chickpea seed yield with those affecting wheat grain yield. Exp. Agric. 1995, 31, 39-47. [CrossRef]

37. Shrestha, R.; Turner, N.C.; Siddique, K.H.M.; Turner, D.W. Physiological and seed yield responses to water deficits among lentil genotypes from diverse origins. Aust. J. Agric. Res. 2006, 57, 903-915. [CrossRef]

38. Mishra, B.K.; Srivastava, J.P.; Lal, J.P.; Sheshshayee, M.S. Physiological and biochemical adaptations in lentil genotypes under drought stress. Russ. J. Plant Physiol. 2016, 63, 695-708. [CrossRef]

39. Mishra, B.K.; Srivastava, J.P.; Lal, J.P. Drought resistance in Lentil (Lens culinaris Medik.) in relation to morphological, physiological parameters and phenological developments. Int. J. Curr. Microbiol. Appl. Sci. 2018, 7, 2288-2304. [CrossRef]

40. Schmidtke, K.; Neumann, A.; Hof, C.; Rauber, R. Soil and atmospheric nitrogen uptake by lentil (Lens culinaris Medik.) and barley (Hordeum vulgare ssp. nudum L.) as monocrops and intercrops. Field Crop Res. 2004, 87, 245-256. [CrossRef]

(C) 2019 by the authors. Licensee MDPI, Basel, Switzerland. This article is an open access article distributed under the terms and conditions of the Creative Commons Attribution (CC BY) license (http:/ / creativecommons.org/licenses/by/4.0/). 